This is the pre-copyedited version of an article published in Culture and Religion:

An Interdisciplinary Journal, 2015, 16(2): 193-214 (special issue The Aesthetics of Religious Authority), copyright Taylor \& Francis.

URL: http://www.tandfonline.com/doi/full/10.1080/14755610.2015.1058530

\title{
A Moment of Persuasion: Travelling Preachers and Islamic Pedagogy in the Netherlands
}

\author{
Daan Beekers \\ d.t.beekers@uu.nl \\ Department of Philosophy and Religious Studies, Utrecht University, Utrecht, The \\ Netherlands
}

\begin{abstract}
In this article, I examine the discursive as well as embodied and sensorial forms of persuasion that undergird the formation of religious authority, Islamic authority in the Netherlands more specifically. I argue that particular momentary occasions can play important roles in facilitating the mobilization of these discursive and non-discursive forms of persuasion. Based on a close reading of an event I participated in during my fieldwork among young Muslims in the Netherlands, the analysis focuses on such a key moment of persuasion, paradoxically characterised by a preacher's apparently failed attempt at conversion. Despite this failure, this preacher can be seen to have succeeded in offering his young Muslim audience a model of how to be a Muslim and of how to represent Islam to non-Muslims. Apart from contributing to anthropological debates on Islamic authority in Europe and religious persuasion more generally, I discuss an important new type of Islamic leaders - referred to here as 'travelling preachers' - and the new kinds of youth-centred settings of religious learning in which they operate.
\end{abstract}

Key words: Islam, Authority, Event, Aesthetics, Europe, the Netherlands 
Before Abu Said ${ }^{1}$, a Moroccan-Dutch preacher who enjoys considerable popularity among young Dutch Muslims, steps forward to give his talk, a microphone is brought over to a girl

sitting at the very back of the audience. She has just asked the previous speaker how she could be convinced to become a Muslim. As her question had already been addressed, it is not clear why she is now being given a microphone. I sense a feeling of increasing excitement and anticipation in the audience around me. Is she supposed to say something? Is it possible that she already wants to pronounce the confession of faith, which marks one's conversion to Islam? 'Do you feel what I feel?'2 I hear a young man behind me ask his friends.

Based on fieldwork in the Netherlands, ${ }^{3}$ in this article I discuss a Dutch Muslim preacher's attempt at conversion that seemed to fail. By interrogating this case, I identify a kind of authority figure that takes an important place in the religious landscape of young Dutch Muslims today, which I refer to here as 'travelling preachers'. These preachers operate in new kinds of youth-centred settings of religious learning, where they answer to young Muslims' desire for religious knowledge. I will show that the apparent failure of the preacher in my case conceals his (partial) success, precisely in terms of the pedagogical work he performs for his audience. I argue that such pedagogical work, and the means of persuasion it implies, may importantly rely on certain singular events. Thus, the empirical case I focus on in this article concerns a momentary occasion that provides the preacher with a favourable opportunity for mobilizing discursive and embodied forms of persuasion, while it provides the audience with an exceptional opportunity for religious learning.

\section{Islamic authority in Europe}

Religious authority has become one of the main issues of inquiry in anthropological research on Muslims in Western Europe. In the context of debates about the accommodation of Islam in Europe, and the possible emergence of something like a 'Euro-Islam'(Douwes 2001; AlSayyad and Castells 2002; Nielsen 2007), anthropologists have increasingly studied the extent to which Islamic authority is being transformed among (young) Muslims in Europe. As Frank Peter (2006) showed in a review article of this literature, a dominant theme in these studies has been the 'fragmentation of authority' among young Muslims in Europe, a process characterized by the 
declining influence of traditional religious institutions such as mosques, imams and Islamic scholars, and by the individualisation of religious beliefs, practices and knowledge acquisition. Young Muslims, the argument goes, have increasingly come to define for themselves what counts as 'true' Islam, as they pick their way through the range of available - and, due to the new media, easily accessible - sources and models of Islam. Scholars like Mandaville (2001), Cesari (2003) and Roy (2004) have given influential versions of this thesis, which however vary with regard to the causes of authority fragmentation, and to its outcomes in terms of such issues as religious liberalization, societal integration and conformity to dogma (see Peter 2006, 106-9 for a discussion).

In recent years, however, scholars working in this field have increasingly argued that (more or less established) religious institutions and authorities continue to be important for Muslims in Europe, including the so-called second and third generations, especially in relation to their attempts at acquiring reliable religious knowledge and fashioning pious selves (AmirMoazami and Salvatore 2003; Jouili and Amir-Moazami 2006; Jacobsen 2011, 257-70). Building on Asad's conceptual work on discipline and tradition (Asad 1986; 1993), these scholars point out that (young) European Muslims' pursuit of the 'correct' tenets of Islam is necessarily dependent on their engagement with, and conformity to, authoritative discourses, institutions and religious scholars (see esp. Jouili and Amir-Moazami 2006). Following Charles Hirschkind (2001) and Saba Mahmood (2005), these authors reject a simple dichotomy between resistance and conformity, or between personal autonomy and subjection to the community, emphasising that submission to religious authorities can be a deliberate act by Muslims - they look primarily at youth and women - in their quest for spiritual self-fulfilment (Jouili and AmirMoazami 2006; Bracke 2008; Jacobsen 2011, 325-9). These studies offer an important corrective, not only to popular-academic and journalist accounts of alleged simple religious indoctrination, but also to analyses of individualisation, especially those that depict young European Muslims as free-floating consumers in a religious marketplace. As will become clear, my discussion will build on both approaches, by looking at shifts in forms of Islamic authority as well as the continued importance of institutional settings in which religious subjectivities are 
shaped. Yet, it will take leave of both by shifting the focus away from the domain of reasoned deliberation.

What both lines of argument have in common, indeed, is their emphasis on individual reasoning. In the first perspective, Muslim individuals are understood to decide for themselves what they accept as 'true' Islam, in the second perspective they are seen to deliberatively choose to submit themselves to Islamic authorities. While individual reasoning is an important aspect of the way authority is accepted, (re-)asserted or contested by Muslim and other religious believers, it can only partially explain how and when believers come to adhere to particular articulations of religious authority. I therefore propose to complement the focus on individual reasoning with a broader inquiry into the processes of persuasion that undergird the constitution of religious authority. ${ }^{4}$

\section{The aesthetics and temporality of persuasion}

Persuasion, in its meanings of 'inducing successfully' and 'causing to believe' (Collins English Dictionary), is related to authority in that it implies the exercise of influence through communication (Dillard and Pfau 2002, ix). In Aristotle's analysis of rhetoric and its 'proper modes of persuasion' (Aristotle 2010), which has received renewed philosophical and social scientific interest in recent decades (see e.g. Rorty 1996), judgements about the proper means of persuasion should be based on the nature of one's audience and should include both rational and emotional elements (Triadafilopoulos 1999, 745; Dillard and Pfau 2002, ix). Approaching religious authority through the processes of persuasion, thus understood, makes it possible in my view to shift our attention to two important aspects of authorization: the role of embodied forms of persuasion on the one hand and the situational and temporal nature of persuasion on the other.

With regard to the former, Birgit Meyer (2010) has introduced the term 'aesthetics of persuasion', taking 'aesthetics' in the Aristotelian sense of aisthesis, which refers 'to our total sensorial experience of the world and to our sensuous knowledge of it' (Meyer and Verrips 2008, 21; cf. Meyer 2010, 761). The notion 'aesthetics of persuasion' implies that persuasion - in religious and other domains of social life - does not only come about by discursive registers and forms of reasoning, but also by the evocation of sensorial experience. In relation to the formation 
of religious authority, aesthetics of persuasion can be taken to refer more specifically to the aesthetic dimensions of the 'process through which authority gets acknowledged and incorporated into people's life worlds' (see the Introduction to this special issue).

The linked dimensions of situationality and temporality point to the important role of momentary episodes in processes of persuasion. In these momentary episodes, the coming together of different actors and conditions provides singular occasions for the effective mobilization of discursive and non-discursive forms of persuasion. Here, I am not primarily thinking of individual experiences of conversion as moments of sudden and immediate transformation (as epitomised by the conversion of Saint Paul, see Badiou 2003; cf. Robbins 2010), but rather of auspicious social occasions in which (aspiring) religious leaders, teachers or preachers find particularly fertile opportunities to persuade an audience of certain teachings, meanings or exemplary behaviours, and thereby establish their own authority. These occasions can be seen as 'events' in the sense of key moments in which something vital is at stake, something memorable is taking place and new social meanings or practices are generated (Jackson 2005, xxix-xxx; Hoffman and Lubkemann 2005, 324). ${ }^{5}$

For individual believers, then, persuasion should be seen not only as a product of reasoned deliberation, but also as something that - at least in part - 'happens to them', by way of their embodied engagement in such momentary episodes. These occasions may often take a sensational character in both implications of the term: spectacular and appealing to the senses (Meyer 2010, 742). They point our attention to the temporal contexts in which persuasion occurs, or to, what has been described from the perspective of political communication research as the 'connection between contexts as particular events, and specific acts of persuasion' (Lorenzo 1996, 3).

\section{'What could convince me to become a Muslim?'}

On a Friday afternoon in the spring of 2010, I attended an activity of the Muslim student association An-Nur in one of the largest cities in the Netherlands. I expected this event to be like many others that I went to during that period, as it was set up in the usual way: It took place in one of the lecture halls of the city's main university and there would be a couple of talks by 
guest-speakers as well as a recitation from the Quran and a Q\&A session. However, as the afternoon progressed, something happened that made this event quite different from others of its sort.

An-Nur is one of a number of student associations run by Muslims in this particular Dutch city. While it does not primarily present itself as a 'Muslim' or 'Islamic' student association but rather as a 'multicultural' one, ${ }^{6}$ it caters to a Muslim student audience, it usually organises events around religious themes and it has a name that is derived from the Islamic tradition (a different one from the pseudonym by which I refer to it). Compared to the other Muslim student associations in this city, An-Nur puts a particularly strong emphasis on religious themes such as Islamic knowledge, Islamic prescriptions and the history of Islam. It also regularly organises talks or debates on more socio-political issues, such as the stigmatisation of Muslims in Dutch society. It has a committee of six people that stay on for one year. Most of the committee members are Moroccan-Dutch. The association works with a mailing list rather than fixed membership. They organize around half a dozen public events each academic year. These usually take place in a lecture hall at their university and are generally well attended (with an average audience of around a hundred people), mostly by young Muslim students. The language used is always Dutch.

The theme of this particular event was 'Sunnah', the tradition of sayings, deeds and (tacit) approvals ascribed to the Prophet Muhammad. In the announcement on An-Nur's website it was stated that '[e]venthough we may have studied the Sunnah, we often fail to follow the code of conduct that Muhammad (sws) ${ }^{7}$ has passed on to us', followed, in bold letters, by the question: 'To what extent do you incorporate the Sunnah in your daily deeds?' The convener of the day was Fouad, a 21-year-old Moroccan-Dutch student in Islamic theology, wearing a beard and dressed in a djellaba (a loose-fitting gown that originates from North African societies). There were around 130 young people in the audience, most were Moroccan-Dutch, others were from Turkish, Surinamese and other backgrounds. A majority of around two-thirds of the public consisted of girls. Such gender imbalance was a common sight at the Islamic events for young people I attended during my fieldwork. ${ }^{8}$ Around nine out of ten of the young women wore a veil. Men and women had entered the hall through separate doors, left and right, and they were also 
seated at opposite sides of the audience. The organization made sure of this, as far as it didn't happen spontaneously.

The afternoon started with a recitation from the Quran by a man in his early twenties, wearing jeans and a sport jacket. The people in the audience listened quietly. This was followed by a talk by Muhammad Amrani, a 34-year-old Moroccan-Dutch man, who runs his own business and regularly gives talks on Islam on the side. He was inconspicuously dressed in trousers and a sweater, and he had a small, short-trimmed beard. He gave an informative, somewhat lecture-like talk, supporting heavily on a PowerPoint presentation, in which he explained the significance of the Sunnah within Islam. His talk was followed by a break. As it was the prescribed time to perform prayer (salaat), people were given the opportunity and directed to places to do so.

When everyone had come back, there was an opportunity to ask Amrani questions. As on other such occasions I attended, most of the questions were not so much about the speaker's talk as about correct Islamic practice more generally. At some point, however, a girl sitting at the very back of the hall asked quite a different question. 'I am searching', she said. 'What could convince me to become a Muslim?' Many of the other members in the audience reacted to her question by applauding and uttering an affectionate 'Ah...'. Fouad, the convener, proposed to have one of the converts in the audience answer her question. After the first of them declined shyly, the microphone went to the second, a man of Dutch descent. At this point, people in the audience had grown silent and expectant. 'I feel the tension in the hall rising, I sense it in my stomach,' I wrote later in my fieldwork diary. 'I have the feeling that the normal course of the night is interrupted and that now something special, something extraordinary, is happening'. The convert calmly and confidently said that Islam appealed to him because 'it explains everything'. There is no vagueness or division, he said, but much emphasis on the unity of God and your direct relation with Him. 'It is super simple. Truth is only to be found in Islam'. Amrani, the first speaker, said that he had nothing to add to these words. He walked up to the girl, I will call her Claire, and gave her the flowers that he had just received after his talk, addressing her as 'the notyet-converted sister'. Again, people in the audience applauded. Subsequently, the stage was 
given to a fairly well-known young Moroccan-Dutch rapper, who read a column dealing with the theme of personal commitment to Islam.

After this it was time for the second speaker, Abu Said, to give his talk. This was the moment a microphone was brought over to Claire. This seemed to cause some wonder and anticipation among the audience, as expressed by the young man sitting behind me: 'Do you feel what I feel?' After a few minutes, Abu Said climbed on stage. His appearance was quite different from Amrani's: He wore sandals and a loosely fitting cotton dress that covered his whole body. His hair was trimmed short, he had a long full beard and his moustache shaved. That is, he had the appearance that is customary among Salafi Muslims, who seek to emulate the Prophet Muhammed and the first three 'righteous generations' of Islam in conduct and appearance (Meijer 2009). Abu Said spoke with ease, powerfully and with a heavy southern Dutch accent. He announced that he would like to ask Claire a few questions.

Abu Said started by asking her whether she believed in God. Claire, who was seated some 25 meters away from him, answered quite shyly but unreservedly: 'No, I don't notice it at all' (ik merk er niks van). To this, Abu Said reacted somewhat cynically: 'Good... Try managing without oxygen for three minutes and then see if you still don't notice it all.' Claire laughed a bit in response. He then pointed to the blackboard behind him and asked her whether or not that had been made by someone. Claire said it had. If everything has a creator, Abu Said pointed out, then surely humans have one too. And, he added, the Creator has determined what is good or bad for you. 'A Muslim finds that delightful. I find it delightful to bow for the One that gives me all these favours.' If you believe in God, he went on to say, you only have to contact Him five times a day. Imagine you'd get five thousand Euros a month if you'd only contact your boss five times a day. 'Also in the morning?', Claire retorted wittingly (probably referring to the early morning prayer). To this, the people in the audience laughed cheerfully. Abu Said continued to say that when you are menstruating your boss grants you leave, and he asked her: 'Do you find that acceptable, logical?'

Abu Said spoke passionately and entertainingly, while now and then reciting verses from the Quran in Arabic. Different from other Muslim speakers that I came to know during my fieldwork, he did not only quote these Arabic verses from the Quran, but recited them in a slow, 
melodious and well-tuned way. These recitations occasioned arresting shifts from his regular speech and seemed both to secure the attention of his listeners and to contribute to something of a sanctified atmosphere. Thus, Abu Said recited some verses from the Quran and explained them: 'Allah forgives the sins of those who follow His path. Allah forgives you everything when you return to Him. We Muslims say: Wonderful! Delightful! That's what I believe in'.

It became clear that Abu Said was not so much getting into a dialogue with Claire, as taking the opportunity to speak at length about the benefits of Islam. He did so by taking Claire through the five pillars of Islam (the Islamic creed, ritual prayer, almsgiving, fasting during Ramadan and the pilgrimage to Mecca) in a playful and metaphorical way, asking her whether she could agree with each of these points. He took his time: the whole session took up to an hour. Midway, some of the people in the audience started to become somewhat restless. Mustafa, a young man seated next to me, was dissatisfied about what was happening, saying 'one needs to speak one-to-one with someone like her'. Indeed, it seemed rather surprising that Abu Said decided to spend the time given to him for his talk on this interaction with Claire (even if it turned out later that he was still allowed to give his talk). It also seemed curious that he chose to have this interaction in front of the entire audience.

\section{Islamic pedagogical spaces and travelling preachers}

Events like this student night illustrate the significance of social settings of religious pedagogy for many young Muslims in the Netherlands. These settings provide spaces in which young Muslims are taught about their religion and stimulated to adhere to its tenets in their everyday lives. Different from the religious settings run by their parents' generation (the 'first generation' Muslim migrants to the Netherlands), these are (co-)organized by young people themselves and commonly characterized by Dutch language use and the relatively young age (generally between around 25 and 45) of teachers, speakers or preachers. They are explicitly tailored to young people's needs of religious learning, offer occasions for interaction between themselves and their teachers and include experienced use of audio-visual material and the Internet. ${ }^{9}$

These pedagogical spaces, as I have argued elsewhere (Beekers 2014), help young Dutch Muslims cope with the everyday challenges to their faith encountered in a society characterised 
by value pluralism, moral individualism and consumerism. Thus, different from the widely shared notion that religion in (post-)modern society becomes a primarily private affair, these forms of sociality can be seen to play crucial roles in young Muslims' day-to-day attempts at pursuing, and sustaining, a pious lifestyle - something many of these young Muslims are themselves highly aware of. It should be noted, in passing, that social settings of religious pedagogy play a similarly important role among young Dutch Christians (ibid.). The significance of supportive communities marks neither a unique situation for Muslims nor an exclusive issue of 'Islam in the West'. These pedagogical settings can be seen both as disciplinary spaces, in which Islamic - or Christian - subjectivities are cultivated and regulated (Asad 1993, 125, passim), and as spaces in which young believers self-consciously participate in order to learn about their religion and strengthen their personal piety (Jouili and Amir-Moazami 2006).

Young Muslims' participation in these settings is however not set in stone, but dependent - next to the influence of peers, parents and other relevant others - on the extent to which they feel that a particular pedagogical setting is useful for them. In other words, these settings are not necessarily binding (cf. De Witte 2009, 184), as young Muslims can quite easily choose to attend one rather than another. Even if dropping out from, say, a mosque class might be difficult, for instance when one's best friends urge one to stay on, there are few formal or structural means of binding people to such settings. This means that it is crucial for the organizers, preachers or teachers of these settings to persuade the people in their audience, to draw their interest and to, as it were, capture them. This implies their need to establish their authority, not only in terms of religious knowledge, but also in terms of their ability to offer an appealing pedagogical space. Discursive, embodied and temporal forms of persuasion are all important in this context. And it is in this regard that a new 'type' of Islamic preachers plays a particularly important role.

Abu Said can be seen as an exponent of a relatively new kind of actors in Dutch Muslim communities, whom I refer to as 'travelling preachers': Islamic preachers who move around the Netherlands to give talks in mosques, universities or other institutions - usually organized by Muslim (or 'multicultural') student associations, mosque youth organizations, institutions of religious education or other Muslim (youth) associations. Since the year 2000 or so, these 
preachers have taken an increasingly important place in the field of religious pedagogy among young Muslims in the Netherlands. ${ }^{10}$ They are usually young men (only very rarely women), often in their thirties or early forties, who commonly grew up in the Netherlands themselves and are therefore familiar with the life-worlds of the young Muslims they address. They preach in Dutch, often using popular (youth) language (cf. Roex et al., 2010, 28, 39-40), while clothing and authorising their speech with Arabic by using religious phrases, Islamic terms and quotations from the Quran. They are commonly 'self-made' preachers, as they have often not enjoyed a formal theological training but educated themselves, based on informal lessons with senior preachers or religious scholars, extensive self-study and sometimes a few years at one of the major Islamic universities, usually combined with a secular education. Most of them have regular paid jobs next to their preaching activities (ibid., 39).

These travelling preachers have come to play an important role in the religious formation of young Dutch Muslims, who apart from attending their talks often listen to, or watch, such talks on the Internet. While more traditional Islamic leaders - who usually preach and teach in Arabic, Turkish or other non-Dutch languages, and who have usually been raised and taught outside of the Netherlands - often continue to be regarded with respect and esteem, ${ }^{11}$ the style and (Dutch) language of travelling preachers tend to resonate better with the life-worlds of young Muslims. This new kind of leaders, it must be added, also include English-speaking transnationally travelling preachers such as Khalid Yasin, Bilal Philips and Sheikh Haitham alHaddad (to mention some of the preachers who enjoy popularity among young Muslims in the Netherlands).

The figure of the travelling preacher can be related to two types of (partly new) Islamic leaders that have been identified in the literature - 'leaders' is used here both in the minimal sense of addressing an audience and leading the dialogue with that audience, and in the more substantial sense of acquiring an audience and exerting influence over that audience. The first are the 'new Muslim intellectuals', described both in the literature on Muslim-majority societies (Eickelman and Piscatori 1996, 13; Hefner 2004, 8) and in that on Europe (Van Bruinessen and Allievi 2011, viii; Morgahi 2011, 57). These are 'men (and occasionally women) whose main education is in another discipline than traditional Islamic studies but who are strongly committed 
to Islam and have acquired sufficient knowledge to speak confidently about matters of religion and its social relevance' (Van Bruinessen and Allievi 2011, vii). The second type, partly overlapping with the first, are the $d u^{\text {' }} a t$, those who undertake $d a$ ' $w a$, by calling others to act in accordance with Islamic norms (Mahmood 2005, 57-64; Hirschkind 2006, 56-8). ${ }^{12}$ Mahmood (2005) and Hirschkind (2006) have described this class of religious actors as an important part of the vanguard of the Islamic Revival that has emerged in Egypt and elsewhere since around the 1970s. Like the 'new Muslim intellectuals', $d u$ 'at often hold degrees in nonreligious subjects and obtained their religious knowledge through self-study or informal apprenticeship. They are esteemed by their audience for their Islamic knowledge, but they are not regarded as 'ulama (formally trained religious scholars). Hirschkind notes that 'they are less bearers of established religious authority than exemplary figures of a form of modern piety and activism' (ibid., 56-7). According to this author, the rise of $d u$ 'at marks a shift in authority from formal religious bureaucracies to the alternative institutional infrastructure associated with the Islamic Revival.

The rise of these travelling preachers, and the new pedagogical settings in which they move, can be situated in the context of the grown influence of the Salafi movement in the Netherlands (Roex et al., 2010). 'Salafism' is a charged term that, certainly in the Netherlands (De Graaf 2011), has acquired negative connotations, evoking images of extremism, radicalism and terrorism. Most preachers actually abstain from using the term themselves, partly for this reason, but also because they would regard it as presumptuous to do so (Roex et al., 2010, 71). The Salafi movement is however very broad and cannot be reduced to extremism. ${ }^{13}$ Rather, it is characterized by 'a puritanical approach to the religion intended to eschew religious innovation by strictly replicating the model of the Prophet Muhammad' (Wiktorowicz 2006, 207). In his work on Salafism in the Netherlands, Martijn de Koning argues that it should be seen as a utopian movement that 'aims to revitalize Islam based upon an idealized vision of the life of the first Muslims [the salaf]' $(2013,73)$ and that thereby seeks to develop a lifestyle and a moral community that are deemed more just, virtuous and satisfying than Muslims' existing lifestyle and community (De Koning 2011, 49-50; 2013, 73).

Dutch manifestations of Salafism, I observed during my fieldwork, are characterized primarily by their attempts at shaping pious subjectivities, rather than by explicitly political or 
societal goals (cf. De Koning 2011, 50). Indeed, much like such movements as Christian evangelicalism (Roeland 2009; Klaver 2011), Salafism can be seen as a transnational revivalist movement with considerable influence among Dutch believers, encouraging them to work on their personal piety in accordance with the sacred scriptures. Salafism, again like evangelicalism, puts considerable emphasis on proselytisation, or $d a$ ' $w a$, the activity of 'inviting' or 'summoning' others to Islam. $D a$ 'wa can denote attempts at converting non-Muslims to Islam Muslims sometimes use the terms 'returning' or 'reverting' rather than 'converting', building on the notion of Islam as din-al-fitrah, the 'natural religion' (Jacobsen 2011, 298) - but nowadays it most often entails the activity of '[urging] fellow Muslims to greater piety' (Mahmood 2005, 57). Abu Said's preaching work is characterised precisely by such concerns with $d a$ ' $w a$, inspired by Salafi interpretations of Islam.

\section{Persuasive preaching}

The ascent of this new kind of Islamic leaders, in the context of new religious pedagogical settings, reflects the significance of the issue of persuasion. Thijl Sunier $(2009,20)$ notes that among European Muslims 'a shift has taken place from representative religious leadership (based on formal criteria of representation) to a performative style of leadership (based on certain leadership qualities)'. Indeed, travelling preachers like Abu Said do not have a fixed constituency, but rather have to gain a public by speaking and acting in ways that are informative, moving and rhetorically appealing. They 'must convince rather than represent' (ibid., 22). Young Dutch Muslims in the Netherlands, as elsewhere in Europe (Jouili and AmirMoazami 2006; Jacobsen 2011, chap. 5), express a strong desire for acquiring religious knowledge, to be able to better understand their religion and explain it to others, but also to attain correct practices of worship. Thus, they importantly judge Islamic preachers and teachers on the basis of their ability to convey such knowledge. Yet, such successful conveyance of religious knowledge does not only rely on the content of the message, but also on the persuasive and performative capacities of speakers (cf. Sunier 2009, 23). Thus, Fatima, a twenty year-old student in psychology who has been actively practicing her religion since she was thirteen, 
explained to me that whether or not religious talks help her to keep her faith (iman) strong, depends on the emotional quality of these talks:

'If someone is simply standing there and talking as if [laughingly:] it is all read from paper, which in fact it is, then it doesn't move you at all [dan doet het niks met je]. Apparently it also doesn't move him. You don't see that feeling, you don't see that emotion, to put it that way. While if someone talks very passionately and is very convinced of what he says and conveys things in a very, uhm, lively way, then you become involved, then you also sort of get that feeling, then you are being drawn into that narrative [meegetrokken in dat verhaal].'

The importance of the performative and aesthetically appealing qualities of preaching first became clear to me during my fieldwork when I learned more about one particular preacher in the Netherlands, whom I will here call Omar Khalil, a Moroccan-Dutch man of around forty years old. Khalil is one of the most popular travelling preachers among young Muslims in the Netherlands and he has actually been the teacher of Abu Said. He is frequently asked to come and talk by youth mosque committees and youth organisations around the country. His sermons, available as podcasts online, have each been downloaded thousands of times. The young Muslims I talked to about this preacher told me that they appreciate him for his knowledge and for the straightforward way in which he tackles - sometimes sensitive - issues. Yet, another important dimension of his appeal concerns his voice. Khalil speaks in a markedly calm and authoritative manner and, as some of my interlocutors pointed out to me, he enunciates particularly well. Indeed, he pronounces his words very clearly, often putting a large emphasis on the last letters of words, especially d's or t's (as in gebed, the Dutch word for 'prayer'). This gives an air of both authority and formality to his language. Some of my interlocutors also noted with approval that this pronunciation makes him sound more 'Dutch'. Thus, one young man once told me that when he first saw Khalil after he had listened to some of his sermons online, he was surprised to find out that the preacher was 'not Dutch'. This statement is problematic in its assumption of a narrow and ethnic - albeit widely shared - definition of what 'being Dutch' 
entails (Yanow and van der Haar 2013). At the same time it can be seen to confirm the importance of Dutch language use by travelling preachers and to suggest that the ability to speak 'proper' Dutch (without the trace of any accent) is a status marker for these preachers. Tellingly, some younger preachers appear to emulate Khalil's style and way of speaking, by talking slowly and authoritatively and by, like him, emphasising the last letters of words.

The positive appraisal of Omar Khalil's voice also points to the significance of his audience's sensorial appreciation of his speech, particularly the qualities of his voice. Amane - a student in Dutch law of 22 who spent much time on learning about Islam, among other things by frequently attending religious talks - told me that while she normally does not like to listen to sermons without seeing the person who is speaking, this is different in the case of Khalil:

'Because I enjoy listening to his sermons so much. He has such a nice voice [prettige stem], that it doesn't matter to me'. The point came up because, on the Internet, Khalil can only be listened to. Unlike most other preachers, he does not want to be videotaped. Consequently, one can find dozens of audio-files of his sermons on the Internet, but no video-files (at least none in which his image appears). Thus, many young Muslims only know Khalil by his voice. This is especially the case for women, who rarely get the opportunity to see him due to the separation of male and female audiences in most places where he speaks (whereby the women sit in a different room from that of the speaker). Thus, while voice is already a primary medium when it comes to the relation between preachers and their audiences (Schulz 2012), this is even more so for Khalil. In his case the 'aesthetics of persuasion' (Meyer 2010) centre on his voice - and thus on his listeners' sense of hearing - rather than other sensory dimensions. ${ }^{14}$ By contrast, Abu Said can be characterised as much by the ways he uses his voice as by the more visual aspects of his embodied performance.

Abu Said lives in a town in the south of the Netherlands and teaches physical education at a primary school. He is in his early thirties and of Moroccan descent. In Dutch Muslim youth communities, particularly among Moroccan-Dutch, he is widely regarded as a talented speaker and therefore a popular asset to the line-up of Islamic youth conferences and events. He took up preaching around $2005^{15}$ and he has over the past years 'started to get a public' (a phrase a more senior preacher used when I talked with him about another upcoming preacher). He is 
particularly appreciated for his ability to affect his audience emotionally. He is often described in announcements as 'someone who knows how to touch our hearts'. His talks, indeed, are characterized by his strong embodied performance, verbal qualities and passionate expression.

This is evident in Abu Said's performance at the An-Nur event described here, as well as in other talks by Abu Said that I have attended. What can be noted here first is his physical appearance. While he is a short man, his appearance is striking because of his 'Islamic' dress and beard. When he takes the stage he attracts attention, not only because of the way he looks, but also because of his self-confident movements and body language, and his calm, authoritative voice. His language is accessible and appealing. Like many other travelling preachers, he constantly addresses his listeners with the terms 'brothers and sisters', thereby repeatedly asking their attention and implying that his audience and he himself belong to a shared communal family. He speaks entertainingly and regularly makes jokes. His talks exhibit quite a powerful rhetoric, as they are well structured around compelling arguments and entail pleas to his audience's assent. As we have seen in his interaction with Claire, he presents the tenets of Islam to her in a way that stresses their reasonableness and self-evidence, and he asks her whether she can agree with these. Similarly, he puts much emphasis on the happiness, joy and peace that result from being a Muslim. Further, he establishes his position as an authoritative preacher by his frequent references to, and quotations from, the Quran and the Sunnah.

Abu Said's rhetoric is strengthened by the ways in which he seeks to engage the senses and rouse emotions in his audience. Most striking in this regard is his style of reciting the Quran. ${ }^{16}$ Hirschkind argues that Islamic preachers play a mediating role, 'providing the linguistic and gestural resources through which the listener can undertake the ethical labor involved in properly attuning his or her faculties to the word of God' $(2006,39) .{ }^{17}$ From this perspective, Abu Said's engaging and melodious style of recitation can be understood to appeal to his listeners' senses and emotions, thereby increasing their receptivity to the words of the Quran. This entails a receptivity not only to the discursive content but also to the embodied experience of the Quran. As Anna Gade $(2004,23)$ points out, 'the Qur'ān is often better understood in Muslim religious life worlds as an activity and an experience over and above a written "text"'. The recitation of the Quran, then, is seen in Islamic doctrine as 'a primary 
medium for manifesting the affecting presence of revelation' (ibid., 39), situating speaker and listeners 'within the sacred paradigm of God's address to mankind' (Martin 2005, 9202). Thus, Abu Said's evocative way of presenting God's words - in the double sense of uttering them and of making them present - can be understood to enable, or at least invite, his audience not only to take note of, but also to participate in a divine revelation (cf. Gade 2004, 25).

Abu Said can be further seen to rouse emotions in his audience by his repeated use of Islamic terms and phrases (such as the invocation to God, 'Ya Allah!' ['Oh God!'], which he sometimes uses as a recurrent component of his speech) and by creating suspense, in this case by having a microphone brought over to Claire without the audience knowing what was going on. In sum, Abu Said makes use of different registers of persuasion, including embodied and sensorial ones, by which he seeks to convince his audience of the truthfulness and value of his message, and to establish himself as a popular and authoritative speaker. While at the An-Nur event these registers of persuasion had a bearing on the entire audience, they were explicitly directed at Claire, who had asked what could convince her to become a Muslim. Now, did Abu Said indeed convince her?

\section{To convert or not to convert}

After Abu Said had guided Claire through the five central tenets of Islam and made sure that she had said 'yes' to all of his questions (even if not all of these affirmative answers appeared equally convinced), he said: 'You have now said "yes" five times, do you know what that means?' Claire responded: 'That I have to become a Muslim?' 'No, no', Abu Said answered, 'but God has chosen you out of millions! You said "yes" five times, that means that you have said "yes" to the five pillars of Islam. What stops you? You only have to pronounce one little sentence to belong to the family of one and a half billion people' (Abu Said refers here to the shahadah, the Islamic declaration of faith, the pronunciation of which confirms one's conversion to Islam). And he repeated with emphasis: 'What stops you?' The atmosphere in the lecture hall could be cut with a knife. Would she do it? Would she decide to convert to Islam right here and now? 'Nothing', Claire responded to Abu Said's question. But she didn't sound very sure. He said: 'You have already accepted it, actually you are already a Muslim... So, would you repeat 
[the shahadah] after me?' There was a silence for a few seconds. Then, Claire said: 'No, I want to give it more thought.' Abu Said reacted: 'It's your right to do so [Dat is je goed recht]. There is no coercion in Islam'. Still, he advised her not to think too long, because one never knows when one's life comes to an end, and then it would be too late. 'Do you know that feeling when you run very fast to catch your train but just miss it? How do you feel when that happens?' Claire answered: 'Then I take the next train.' Abu Said, again: 'I forgot to say, it is the last train. It's better to get in first and then find your place in Islam.' Now that Abu Said had finished this interaction with Claire, the committee of An-Nur took a minute to discuss how to go on from here. They decided that he could still give his talk, but that we would first take a break and have some sandwiches, which were actually prepared for after the end of the event.

Thus, Abu Said failed to convince Claire to become a Muslim, or at least to do so at that very moment. It is indeed striking that he did try to have her pronounce the declaration of faith, as it seemed quite clear that she was still doubtful. More generally, he appeared to be strikingly confident and assertive in his $d a$ ' $w a$. This makes one wonder how the people in the audience and the organizing committee felt about his act. The responses I have gathered were mixed. When I put the question to Fouad (the convener of the event) during an interview some months later, he answered that from an organizational perspective he was not happy about it. Some people had come from far away to listen to Abu Said's talk and had to go home in time. It mixed up the program. Yet, from a religious perspective he thought it was wonderful. 'It is a beautiful thing to invite others to Islam'. Still, he would not have done it himself. 'I would rather try and speak with her on a one-to-one basis'. Amane, already cited above, was a member of the audience during the event. Reflecting on the interaction between Abu Said and Claire, she told me: 'I think that it was also about his own feelings, like, this is my obligation, I just have to do it. What she does, you know, is her own responsibility, but now I have to fulfil my own obligation.' And, she added, Abu Said acted where the previous speaker 'failed to take the opportunity' [die kans heeft laten liggen]. These responses indicate support for the assertive missionary approach (by performing $d a^{'} w a$ ) undertaken by Abu Said. In this perspective, he was simply doing his religious duty as a virtuous Muslim (Mahmood 2005, 64). 
Yet, as Fouad's words also suggest, such assertiveness was not appreciated equally by all present at the event. For one, the committee of the student association that had organized the event appeared rather dissatisfied about it. One of the committee members was Farida, 23, who worked as an adviser to migrant parents in the fields of upbringing and social integration. Around one year after it had occurred, Farida told me that she and the other committee members were unhappily taken by surprise by Abu Said's initiative, which he had not discussed with them beforehand. When he had begun, Farida quickly assembled the committee to discuss what to do. They considered intervening, but decided not to, since 'after all he is someone who has more knowledge than we do, perhaps he knew better than we did that this was the right thing to do'. Moreover, they did not want to 'compromise his honor [zijn eer aantasten] by getting on stage and asking him to stop'. Farida told me that they did understand why Abu Said did it and that, in the end, he did not do anything wrong, like forcing Claire to convert. Still, they 'would now think twice before inviting him' again. ${ }^{18}$

\section{Pedagogy, persuasion and the momentary}

As Abu Said did not achieve his ostensible goal of converting Claire and as his missionary endeavour received mixed responses from those present, it is tempting to interpret his publicly staged interaction with her as a failed performance. This conclusion, however, should not be drawn too hastily. To appreciate this, it is necessary to look at the incident beyond the primary interaction between Abu Said and Claire, and to return to the issue of pedagogy. Indeed, I argue that the important effect of Abu Said's interaction with Claire concerned not so much her potential conversion right then and there, as what he was demonstrating to the Muslim members of the audience. More than converting Claire, what was at stake was showing the young audience how to go about representing Islam to non-Muslims in an appealing and persuasive way.

This became clear to me after several conversations I had with young Muslims about what had happened. When I told Rachid - a young man I occasionally met at Islamic talks about the event, he said that it was a very good move of Abu Said, as he showed the public how to go about such a conversation about the benefits of being a Muslim. 'As Muslims we often 
encounter situations in which people are interested in Islam and ask us about it, but we don't always know how to react.' Amane made a similar point in our interview. When I mentioned that I was wondering why Abu Said spoke to Claire in public rather than in person, she responded:

Yes, that question is in everyone's mind, but I, uhm, I was actually thankful to him that he did do it. [...] You so often get questions from people. I have also often experienced that, uhm, that for example a girl comes up to me. And she is full of doubt, as in, 'I'd like to become a Muslim, but this and this and this.' And then you don't know how to go about explaining why actually you are a Muslim. You do know it, you can also explain it, but the steps that he takes for example, then you think, indeed, that's how one can do it. In that way it is much clearer, and I also agree with it, and it makes that you think about it. So next time when someone comes up to you with, uhm, with doubts, you know, like, 'and this and this and this', you are able to apply. For sure. So I was really thankful to him actually.

This statement shows not only that Abu Said's interaction with Claire was an event that had made a lasting impression on Amane and others like her, partly due to the controversy it raised ('that question is in everyone's mind'), but also that it had a highly pedagogical value for those in the audience. Abu Said's exchange with Claire can be seen as an encouragement to the young Muslims in the audience to be assertive when it comes to performing $d a$ ' $w a$ (telling others about, and 'inviting' them to, their faith) and at the same time as a demonstration of how to speak about and represent Islam.

More particularly, Abu Said showed in what ways representing Islam may entail both arguments, metaphors and forms of reasoning, and the evocation of sensorial and emotional experience as well as embodied performance. Next to the argumentative strategies of $d a$ ' $w a$, he provided examples of its aesthetic dimensions, expressed especially in his comportment and manner of speaking, his melodious and engaging recitations from the Quran, as well as his dress and appearance. Thus, Abu Said demonstrated that religious persuasion goes beyond 'presenting 
pure knowledge alone' and includes 'the effective use of particular styles that appeal to the senses and invoke emotions' (Meyer 2010, 756-7). What is more, his performance makes clear that the realms of deliberative reason and embodied experience cannot be strictly separated from one another. In Abu Said's and other preachers' acts of persuading their audience, these realms can be seen as strongly intertwined and mutually re-enforcing. Similarly, in the religious pedagogies to which these preachers give shape, discursive and embodied elements work together and complement one another in the fashioning of religious subjects.

In the pedagogical setting described here, Abu Said's performance did not only set an example of $d a$ ' $w a$, but also provided a reminder to his young audience of how to talk, dress and use their bodies in 'properly' Islamic ways in their everyday lives. Indeed, while the appearance and speech of most of the young people in the audience that night was not as explicitly Islamically coded as that of Abu Said, during my fieldwork with these young Muslims I noticed that elements of the kind of pious subjectivity embodied by such preachers were being reproduced by them, for example by growing a beard, infusing their speech with Islamic expressions or referring to events in the life of the Prophet.

The significance of the dimension of pedagogy here should be seen in the light of the aforementioned important role of social settings of religious learning for young Dutch Muslims. These young believers frequently attend Islamic talks, conferences, classes, sermons and other events in order to learn about their religion and to find the structure they feel they need to sustain and improve their personal piety in the context of a society in which such a structure is not selfevidently given. Abu Said is received so well among these young Muslims, I suggest, precisely because he is not only knowledgeable about Islam but also because he has the capacity to 'demonstrate Islam' - and, indeed, to demonstrate how to present Islam to non-Muslims through his verbal as well as non-verbal performance. He thereby gives shape to a persuasive pedagogy by which he secures the attention, and possibly the attachment, of a young Muslim public that is not formally or structurally bound to him.

In the case discussed here, such persuasive pedagogy was importantly made possible by the memorable and exciting event created by Abu Said's somewhat bold liberty to intervene in and thereby 'mix up' - the expected course of events. Claire's question presented a singular 
occasion in which the combination of different actors and conditions - a potential convert, a travelling preacher and a young Muslim audience, brought together in the context of an activity organised by a Muslim student association - provided Abu Said with a particularly good opportunity to fulfil the pedagogical role that young Muslims desire from preachers like him, to stage a persuasive performance, and to strengthen his reputation and leadership position. After Amrani, the previous speaker, had 'failed to take the opportunity' as Amane put it, Abu Said could step up and capitalise on the momentary occasion by initiating his public act of $d a$ ' $w a$. This act contributed to a memorable and sensational event, a particularly propitious moment for a persuasive pedagogy to take effect, which is suggestive of both the aesthetic and the temporal aspects of the processes of persuasion underlying Islamic and other kinds of religious authority.

\section{Acknowledgments}

I am grateful to the editors of this special issue, Martijn de Koning, Marleen de Witte and Thijl Sunier, for their helpful comments and suggestions on a draft of this article. I also thank Birgit Meyer, Anton van Harskamp, Paul Mepschen and Markus Balkenhol for their critical engagement with earlier versions of this paper. Versions of the paper were presented at the Leiden-VU Anthropology PhD Seminar on 'Figures' at Leiden University (June 28, 2011), the seminar 'The Aesthetics of Religious Authority' at VU University Amsterdam (September 21, 2012) and the conference 'Sermon in the City' at the Zentrum Moderner Orient in Berlin (October 31, 2014). I thank the audiences and the discussants (Michael Herzfeld in Leiden and Norman Saadi Nikro in Berlin) at these occasions for their questions and comments. Finally, I would like to express my gratitude to my Muslim interlocutors and to the committee members of the Muslim student association discussed here for having me in their midst. The research on which this article is based was funded by the Netherlands Organisation for Scientific Research (NWO). 


\section{Notes}

${ }^{1}$ All names of persons and organisations in this paper have been replaced by pseudonyms.

${ }^{2}$ I have translated all quotes from my fieldwork and interviews from Dutch into English.

3 This fieldwork was part of a comparative ethnographic study of young Muslims and Christians that I have conducted in the Netherlands (Beekers 2015). The study focused on actively practising Sunni Muslims, mostly of Moroccan background (all interlocutors I quote in this article are Moroccan-Dutch, except for Mustafa, who was born in Azerbaijan), and on Protestant Christians, between 18 and 28 years old, most of whom highly educated. I have conducted fieldwork among these groups in the period between September 2009 and June 2011, during which ten months were spent on intensive day-to-day field research. I have carried out semi-structured, in-depth interviews with 24 young Muslims and 24 young Christians, and extensive participant observation among these groups, especially in the context of student associations, private classes, religious talks, mosques, churches and conferences.

${ }^{4}$ This resonates with the 'processual framing' of the study of Islamic authority that Peter and Arigita (2006, 537-8) propose. These authors advocate a study of the "processes of authorization which might imply a variety of factors and lead to very diverging outcomes in terms of authorities and religious institutions of authority' (ibid., 538). Yet, the approach I suggest here is different from theirs in that I emphasize the non-discursive and temporal aspects of processes of persuasion.

5 Theoretical approaches to 'events' have been very diverse. An issue of debate that has recently received considerable attention in anthropology is the question to what extent events involve a radical rupture from the preexisting social fabric and a new beginning - in the way theorised by Badiou (2005). For different positions, see for example Humphrey (2008), the collection of articles in Engelke and Robbins (2010), and Coleman (2011). As noted above, in my analysis the focus does not lie on events as moments of radical transformation, but rather on events as exceptionally auspicious moments for persuasion to take effect.

${ }^{6}$ Dutch student associations organised around - and focusing on - Islam, more commonly present themselves as 'multicultural'. This label appears to be more acceptable than 'Islamic' in the context of secular norms predominating in the Dutch public sphere, as it expresses a more pluralist and secular character. Moreover, in the light of current negative sentiments towards Islam, the term 'Islamic' could easily ignite controversies, criticisms or suspicions. Tellingly, Christian student associations, by contrast, generally use the term 'Christian' to describe themselves.

7 'Sws' stands for sallahu allaihi wa sallam (peace and blessings be upon him), a formula that is commonly used by Muslims after the Prophet is mentioned. 
${ }^{8}$ This gender imbalance, with more young women than men attending Islamic events, has also been observed in other European contexts (see e.g. Gerdien Jonker cited in Jouili and Amir-Moazami 2006, 638n2). This is a striking phenomenon, yet unfortunately I do not have the space to elaborate on it here.

${ }^{9}$ Take for example the website Islaamtv.nl, run by an enthusiastic group of young people who frequent Islamic events and register these on video, in order to stream or archive them on their website.

${ }^{10}$ Martijn de Koning, personal communication.

${ }^{11}$ In this regard I would nuance the regularly expressed idea that young European Muslims are dissatisfied with imams who primarily target their parents' generation (see e.g. Mandaville 2001, 123-4; Vertovec 2001, 112-3; Dessing 2005, 10).

${ }^{12}$ Both categories of Islamic leaders can also be related to what Werbner describes as 'lay preachers' (1996, 112-3).

${ }^{13}$ Wiktorowicz' (2006, 216-28) division of the Salafi movement in three broad categories - purists (or isolationists), political Salafis and jihadis - has been influential in the literature. Following this scheme, Roex et al. (2010, 23) note that the category of political Salafis are the most visible and well-organized in the Netherlands. Political Salafis advocate engagement with media and politics and stand for an active Islamisation of individuals, family and society. Like the great majority of Salafis in the Netherlands, they do not sanction violence as a means to achieve their goals (ibid., 21).

${ }^{14}$ In her work on female radio Muslim preachers in Mali, Schulz gives close attention to 'the sensuous, aesthetic, and expressive qualities of voice, and [...] its cultural construction as a knowledge medium' $(2012,25)$. She shows, among other things, that for the women that listen to these preachers, the latter's voices are understood to have 'touching' and 'moving' effects (ibid., 38). Schulz particularly addresses the possibilities as well as insecurities that result from the dissociation of voice and body through media technologies such as the radio. This could also be a fruitful lens to look at the sermons that are widely available on the Internet in audio-format, such as those of Omar Khalil, yet I do not have the space to do so here.

${ }^{15}$ Martijn de Koning, personal communication.

${ }^{16}$ Abu Said can be placed in a long tradition of the art of vocal performance in reciting the Quran (Gade 2004; Hirschkind 2006, 80). Many of my interlocutors told me that they liked listening to such recitations of the Quran (often through Internet podcasts or Youtube), especially those from famous reciters from Mecca and Medina.

${ }^{17}$ Hirschkind's use of the term 'mediation' here underscores his observation that in the Islamic tradition of preaching that he surveys, the power of persuasion is understood to be located primarily in the miraculous word of God itself rather than in the preacher (see Hirschkind 2006, 33-4, 39).

${ }^{18}$ The committee's dissatisfaction with Abu Said's intervention may indicate a broader - and potentially conflicting - contrast between Salafi preachers like Abu Said and Muslim student associations. While these preachers are 
frequently asked to give talks by many of these student associations, they embody a form of missionary activism that is not always in tune with the associations' aims of being open organisations that are acceptable to different groups of Muslims, non-Muslims and the university's institutions alike. For instance, while An-Nur prioritises the transmission of Islamic knowledge, Farida told me that it does not want to be labelled as an association that tries to convert people.

\section{References}

AlSayyad, Nezar, and Manuel Castells, ed. 2002. Muslim Europe or Euro-Islam: Politics, Culture, and Citizenship in the Age of Globalization. Lanham, MD and Plymouth: Lexington Books.

Amir-Moazami, Schirin, and Armando Salvatore. 2003. "Gender, Generation and the Reform of Tradition: From Muslim Majority Societies to Western Europe." In Muslim Networks and Transnational Communities in and Across Europe, edited by S. Allievi and J.S. Nielsen, 52-77. Leiden and Boston: Brill.

Aristotle. 2010. Rhetoric. Edited by W.D. Ross, translated by W. Rhys Roberts. New York, NY: Cosimo, Inc.

Asad, Talal. 1986. "The Idea of an Anthropology of Islam”. Occasional Papers Series. Washington, DC: Center for Contemporary Arab Studies, Georgetown University. 1993. Genealogies of Religion: Discipline and Reasons of Power in Christianity and Islam. Baltimore: Johns Hopkins University Press.

Badiou, Alain. 2003. Saint Paul: The Foundation of Universalism. Stanford, CA: Stanford University Press.

- 2005. Being and Event. Translated by Oliver Feltham. London and New York, NY: Continuum.

Beekers, Daan. 2014. "Pedagogies of Piety: Comparing Young Observant Muslims and Christians in the Netherlands." Culture and Religion: An Interdisciplinary Journal 15(1): 72-99.

- 2015. Precarious Piety: Pursuits of Faith among Young Muslims and Christians in the Netherlands. Unpublished PhD dissertation. VU University Amsterdam.

Bracke, Sarah. 2008. "Conjugating the Modern/religious, Conceptualizing Female Religious Agency: Contours of a 'Post-secular' Conjuncture.” Theory, Culture \& Society 25 (6): $51-67$.

Cesari, Jocelyne. 2003. "Muslim Minorities in Europe: The Silent Revolution." In Modernizing Islam: Religion in the Public Sphere in Europe and the Middle East, edited by J.L. Esposito and F. Burgat, 251-69. London: Hurst and Company.

Coleman, Simon. 2011. "'Right Now!': Historiopraxy and the Embodiment of Charismatic Temporalities." Ethnos 76 (4): 426-447. 
De Graaf, Beatrice. 2011. "Religion bites: religieuze orthodoxie op de nationale veiligheidsagenda." Tijdschrift Voor Religie, Recht En Beleid (2): 62-80.

De Koning, Martijn. 2011. “'Moge Hij onze ogen openen’: de radicale utopie van het 'salafisme'." Tijdschrift Voor Religie, Recht En Beleid (2): 47-61.

—. 2013. "The Moral Maze: Dutch Salafis and the Construction of a Moral Community of the Faithful." Contemporary Islam 7 (1): 71-83.

De Witte, Marleen. 2009. "Modes of Binding, Moments of Bonding: Mediating Divine Touch in Ghanaian Pentecostalism and Traditionalism.” In Aesthetic Formations: Media, Religion, and the Senses, edited by Birgit Meyer, 183-205. New York: Palgrave.

Dessing, Nathal M. 2005. "Secularisatie, maar wat nog meer?" Migrantenstudies 1: 5-13.

Dillard, James Price, and Michael Pfau. 2002. "Introduction." In The Persuasion Handbook: Developments in Theory and Practice, edited by James Price Dillard and Michael Pfau, ix-Xx. Thousand Oaks, CA [etc.]: Sage Publications.

Douwes, Dick. 2001. "Inleiding." In Naar een Europese islam? Essays, edited by Dick Douwes, 9-19. Amsterdam: Mets \& Schilt.

Eickelman, Dale F., and James Piscatori. 1996. Muslim Politics. Princeton, NJ and Oxford: Princeton University Press.

Engelke, Matthew, and Joel Robbins, ed. 2010. "Special Issue: Global Christianity, Global Critique." South Atlantic Quarterly 109 (4).

Gade, Anna M. 2004. Perfection Makes Practice: Learning, Emotion, and the Recited Qur'ān in Indonesia. Honolulu: University of Hawai'i Press.

Hefner, Robert W. 2004. "Introduction: Modernity and the Remaking of Muslim Politics.” In Remaking Muslim Politics: Pluralism, Contestation, Democratization, edited by Robert W. Hefner, 1-36. Princeton, NJ and Woodstock: Princeton University Press.

Hirschkind, Charles. 2001. "Civic Virtue and Religious Reason: An Islamic Counterpublic." Cultural Anthropology 16 (1): 3-34.

- 2006. The Ethical Soundscape: Cassette Sermons and Islamic Counterpublics. New York: Columbia University Press.

Hoffman, Danny, and Stephen C. Lubkemann. 2005. "Warscape Ethnography in West Africa and the Anthropology of 'Events'." Anthropological Quarterly 78 (2): 315-327.

Humphrey, Caroline. 2008. "Reassembling Individual Subjects Events and Decisions in Troubled Times." Anthropological Theory 8 (4): 357-380.

Jackson, Michael. 2005. Existential Anthropology: Events, Exigencies, and Effects. New York, NY and Oxford: Berghahn Books.

Jacobsen, Christine M. 2011. Islamic Traditions and Muslim Youth in Norway. Leiden and Boston: Brill.

Jouili, Jeanette S., and Schirin Amir-Moazami. 2006. "Knowledge, Empowerment and Religious Authority Among Pious Muslim Women in France and Germany." The Muslim World 96 (4): 617-642.

Klaver, Miranda. 2011. This Is My Desire: A Semiotic Perspective on Conversion in an Evangelical Seeker Church and a Pentecostal Church in the Netherlands. Amsterdam: Pallas Publications/Amsterdam University Press. 
Lorenzo, David. 1996. "Political Communication and the Study of Rhetoric: Persuasion from the Standpoint of Literary Theory and Anthropology." In The Theory and Practice of Political Communication Research, edited by Mary E. Stuckey, 1-27. Albany, NY: State University of New York Press.

Mahmood, Saba. 2005. Politics of Piety: The Islamic Revival and the Feminist Subject. Princeton, NJ and Oxford: Princeton University Press.

Mandaville, Peter G. 2001. Transnational Muslim Politics: Reimagining the Umma. London: Routledge.

Martin, Richard C. 2005. "Tilāwah." In Encyclopedia of Religion, edited by Lindsay Jones, Second edition, 9200-9203. Detroit [etc.]: Thomson Gale.

Meijer, Roel, ed. 2009. Global Salafism: Islam's New Religious Movement. New York, NY and Chichester: Columbia University Press.

Meyer, Birgit. 2010. “Aesthetics of Persuasion: Global Christianity and Pentecostalism's Sensational Forms.” South Atlantic Quarterly 109 (4): 741-763.

Meyer, Birgit, and Jojada Verrips. 2008. "Aesthetics.” In Key Words in Religion, Media and Culture, edited by David Morgan, 20-30. London: Routledge.

Morgahi, M. Amer. 2011. "An Emerging European Islam: The Case of the Minhajul Qur'an in the Netherlands." In Producing Islamic Knowledge: Transmission and Dissemination in Western Europe, edited by Martin Van Bruinessen and Stefano Allievi, 47-64. London and New York, NY: Routledge.

Nielsen, Jørgen S. 2007. “The Question of Euro-Islam: Restriction or Opportunity?" In Islam in Europe: Diversity, Identity and Influence, edited by Aziz Al-Azmeh and Effie Fokas, 3448. Cambridge [etc.]: Cambridge University Press.

Peter, Frank. 2006. "Individualization and Religious Authority in Western European Islam." Islam and Christian-Muslim Relations 17 (1): 105-118.

Peter, Frank, and Elena Arigita. 2006. "Introduction: Authorizing Islam in Europe." The Muslim World 96 (4): 537-542.

Robbins, Joel. 2010. “Anthropology, Pentecostalism, and the New Paul: Conversion, Event, and Social Transformation." South Atlantic Quarterly 109 (4): 633-652.

Roeland, Johan. 2009. Selfation: Dutch Evangelical Youth Between Subjectivization and Subjection. Amsterdam: Pallas Publications/Amsterdam University Press.

Roex, Ineke, Sjef Van Stiphout, and Jean Tillie. 2010. Salafisme in Nederland: aard, omvang en dreiging. Amsterdam: IMES-Institute for Migration and Ethnic Studies, University of Amsterdam.

Rorty, Amélie Oksenberg, ed. 1996. Essays on Aristotle's Rhetoric. Berkeley and Los Angeles, CA: University of California Press.

Roy, Olivier. 2004. Globalized Islam: The Search for a New Ummah. London: Hurst and Company.

Schulz, Dorothea. 2012. "Dis/embodying Authority: Female Radio 'Preachers' and the Ambivalences of Mass-mediated Speech in Mali." International Journal of Middle East Studies 44 (01): 23-43. 
Sunier, Thijl. 2009. Beyond the Domestication of Islam: A Reflection on Research on Islam in European Societies. Inaugural lecture. Amsterdam: VU University.

Triadafilopoulos, Triadafilos. 1999. "Politics, Speech, and the Art of Persuasion: Toward an Aristotelian Conception of the Public Sphere." The Journal of Politics 61 (3): 741-757.

Van Bruinessen, Martin, and Stefano Allievi. 2011. "Preface." In Producing Islamic Knowledge: Transmission and Dissemination in Western Europe, edited by Martin Van Bruinessen and Stefano Allievi, vii-ix. London and New York, NY: Routledge.

Vertovec, Steven. 2001. "Moslimjongeren in Europa: vermenging van invloeden en betekenissen." In Naar een Europese islam? Essays, edited by Dick Douwes, 95-115. Amsterdam: Mets \& Schilt.

Werbner, Pnina. 1996. “The Making of Muslim Dissent: Hybridized Discourses, Lay Preachers, and Radical Rhetoric Among British Pakistanis." American Ethnologist 23 (1): 102-122.

Wiktorowicz, Quintan. 2006. "Anatomy of the Salafi Movement." Studies in Conflict and Terrorism 29 (3): 207-239.

Yanow, Dvora, and Marleen van der Haar. 2013. "People Out of Place: Allochthony and Autochthony in the Netherlands' Identity Discourse - Metaphors and Categories in Action." Journal of International Relations and Development 16 (2): 227-261. 